\title{
Obama promises to fix flawed health insurance website
}

$\mathrm{U}$ S President Barack Obama is frustrated with the work of contractors, including Canada's largest technology company, and the sustained problems with the website at the centre of his hard-fought Affordable Health Care Act.

"Nobody's madder than me that the website isn't working as well as it should," the President said in a speech at the White House, "which means it's going to get fixed."

One of the main contractors for the website (healthcare.gov) is CGI Group, based in Montréal, Quebec. It was paid $\$ 93.7$ million to help develop the site, which has been riddled with problems since going live Oct. 1.

The website is intended to allow US consumers access to the new health insurance marketplace envisaged under the act. Coverage offered includes a range of options so consumers can pick a plan that best meets their needs and budget no matter their location. But millions of people hit roadblocks to creating accounts or even registering for health insurance.

Following Obama's speech, White House Press Secretary Jay Carney referred questions about CGI - including one about a cancelled \$46-million contract to build a diabetes registry in Ontario, a project that was beset with problems, as reported in CMAJ last year - to the US Department of Health and Human Services. Dori Salcido, the department's acting assistant secretary for public affairs, did not respond to emails and phone calls from CMAJ. Department Secretary Kathleen Sebelius will testify before Congress later this week.

CGI has not yet responded to a $C M A J$ request for comment on the problems plaguing healthcare.gov.

The Centers for Medicare and Medicaid Services, the federal agency in charge of the website, procured databases and software systems from 55 contractors but has struggled to integrate the products. The government hopes to have fixes in place by Nov. 1 to allow consumers to meet a Dec. 15 deadline to obtain coverage by January.

But those fixes won't be easy, said Obama, describing the urgent effort underway as a "tech surge."

"We've had some of the best privatesector [information technology] talent in the country step forward," said Obama. In the meantime, people should use telephones to buy insurance, the president suggested.

Noting that the politics swirling around the health care reforms have been highly charged, Obama acknowledged that the website debacle amounts to a severe setback for the centrepiece effort of his White House tenure. Obamacare, as it's been called, is seen by many as the president's signature accomplishment. It is also one that Republicans have taken extreme measures to stop, including shutting down the government.
"Let's admit it, the website not working as well as it should makes supporters nervous," Obama acknowledged, while stressing that his health insurance reforms "don't depend on a website" and "the essence" of the reforms are working well.

"The product is good. The health insurance is good," he said. "People can save significant money by buying the insurance available through these marketplaces." Plus the website isn't an unmitigated disaster, Obama added. "So far, the national website healthcare.gov has been visited 20 million times" and "more than half a million consumers have successfully submitted applications through state and federal websites."

CGI Federal, a US subsidiary of CGI Group, was one of 16 companies on a \$4-billion "indefinite delivery, indefinite quantity" contract for upgrading systems for Medicare and Medicaid in 2007. According to USASpending.gov, CGI Federal received $\$ 678$ million for various services. That includes the $\$ 93.7$-million Healthcare.gov contract, won over three other companies in late 2011.

CGI's website states that the company specializes in "creating competitive marketplaces for greater access and coverage" by developing online health insurance and health benefits exchanges. "CGI brings all of this expertise to the table," states the website. - Paul Webster, Toronto, Ont.

CMAJ 2013. DOI:10.1503/cmaj.109-4639 